\title{
1 Taking the Pulse of PyroCumulus Clouds
}

2 C. K. Gatebe 1,2, T. Varnai ${ }^{2,3}$, R. Poudyal 2,4 , C. Ichoku ${ }^{2}$ and M. D. King 5

3 Universities Space Research Association, Columbia, Maryland 21228, USA.

42 NASA Goddard Space Flight Center, Greenbelt, Maryland 20771, USA.

53 University of Maryland, Baltimore County, Baltimore, Maryland 21228

64 Science Systems and Applications, Inc., Lanham, Maryland 20706, USA

$7 \quad{ }^{5}$ Laboratory for Atmospheric and Space Physics, University of Colorado, Boulder, Colo8 rado, USA.

9 Correspondence: charles.k.gatebe@nasa.gov

10 Abstract: Forest fires can burn large areas, but can also inject smoke into the upper 11 troposphere/lower stratosphere (UT/LS), where stakes are even higher for climate, 12 because emissions tend to have a longer lifetime, and can produce significant regional 13 and even global climate effects, as is the case with some volcanoes. Large forest fires 14 are now believed to be more common in summer, especially in the boreal regions, where pyrocumulus (pyroCu), and occasionally pyrocumulonimbus (pyroCb) clouds

16 are formed, which can transport emissions into the UT/LS. A major difficulty in de17 veloping realistic fire plume models is the lack of observational data within fire 18 plumes that resolves structure at 10 w $100 \mathrm{~m}$ scales, which can be used to validate 19 these models. Here, we report detailed airborne radiation measurements within strong 20 pyroCu taken over boreal forest fres in Saskatchewan, Canada during the Arctic Re21 search of the Composition of the Troposphere rom Aircraftand Satellites (ARCTAS) 
1 sammer field campaign in 2008. We find that the angular distribution of radiance

2 within the pyroCu is closely related to the diffusion domain in water clouds and can

3 be described by very similar simple cosine functions. We demonstrate with Monte

4 Carlo simulations that radiation transport in pyroCu is inherently a $3 \mathrm{D}$ phenomenon

5 and must account for particle absorption. However, the simple cosine function prom-

6 ises to offer an easy solution for climate models. The presence of a prominent smoke

7 core, defined by strong extinction in the UV, VIS and NIR, suggests that the core

8 might be an important pathway for emission transport to the upper troposphere and

9 lower stratosphere. We speculate that this plume injection core is generated and sus-

10 tained by complex processes not yet well understood, but not necessarily related di-

11 rectly to the intense fires that originally initiated the plume rise. 


\section{Introduction}

Forest fires are known to burn vast areas, and also inject smoke into the upper troposphere/lower stratosphere (UT/LS), where the stakes are even higher for climate, because emissions tend to have a longer lifetime, and can cause regional and global climate effects, as is the case with some volcanic eruptions. Fires of this nature are common in summer in the boreal regions of Alaska, Canada, and Russia (Fromm et al., 2010; Soja et al., 2007; Stocks et al., 2003).

Large forest lires release enough energy, both sensible and latent heat, to lift the smoke-laden air beyond the condensation level, resulting in the formation of cumulus clouds. Due to their association with fires, these clouds are commonly referred to as pyrocumulus (pyroCu), or pyrocumulonimbus (pyroCb) when convective storms are sufficiently deep to glaciate and form anvils. The pyroCbs have unique dynamical and microphysical structures, and constitute an important mechanism for troposphere-stratosphere transport of biomass burning emissions such as aerosols and trace gases, thereby contributing to raising their budgets in the UT/LS (Damoah et al., 2006; Luderer et al., 2006; Trentmann et al., 2006; Fromm et al., 2005; Fromm and Servranckx, 2003). There is now growing evidence that wildfires should be considered as additional sources of aerosol and trace gases to the UT/LS region, which was previously thought to be primarily dominated by volcanic eruptions (Fromm et al., 2010; Luderer et al., 2006).

There is still significant uncertainty on how much of the energy released by combustion contributes to local heating of the atmosphere and is available for convection, and how much of the energy is lost due to radiative processes. Commonly found estimates for the radiative energy are between nearly $14 \%$ (Wooster et al.,2005) and 50\% (McCarter and Broido, 1965; Packham, 1969). These estimates are based on laboratory studies or observations of small-scale fires, and their application to large-scale crown fires resulting in 
1 pyroCu or pyroCb convection is subject to considerable uncertainty. The interaction of this radiative energy with atmospheric constituents is also highly uncertain. In the thermal in-

3 frared, where most of the fire radiation is emitted (Wooster, 2002), aerosols are rather inef-

4 ficient absorbers. It is likely that most of the radiative energy from the fire is absorbed by 5 cloud droplets or gaseous absorption at cloud base or in air masses that are entrained into

6 the convective plume. This implies that the radiative energy from the fire is trapped in the 7 lower part of the pyro-convection and therefore contributes to the convective energy. It is 8 therefore important to consider the radiative processes in detail.

9 A major challenge in developing realistic fire plume models is the lack of observa10 tional data within forest fire plumes that can be used for validating these models. This is not 11 a big surprise, because making observations within forest fire plumes is challenging at best, 12 and flying into the "core" of rising smoke can be very risky. The possibility of damaging 13 expensive instrumentation is also high. Here, we report detailed radiation measurements 14 from within a pyroCu core taken onboard the NASA P-3B aircraft during the Arctic Re15 search of the Composition of the Troposphere from Aircraft and Satellites (ARCTAS) ex16 periment, which took place in Canada in June-July 2008 (Jacob et al., 2010). Such meas17 urements are needed in the investigations of pyro-convection on the spatial scale of indi18 vidual events, i.e., tens of meters to a few hundred meters. This would contribute to the 19 understanding of the vertical and cross-isentropic transport mechanisms responsible for 20 high-altitude tropospheric and stratospheric injection (Luderer et al., 2006). These radiation 21 measurements are unique; we are not aware of any previous radiation measurements within 22 a forest fire plume at the scales described in the next section.

23 This study focuses on 2 July 2008 and 6 July 2008 , the fourth and sixth flights of the 24 P-3B, respectively, out of Cold Lake, Canada during ARCTAS. These flights provided op25 portunities for in situ observations of flaming fires, plume volution and vertical profles of 
1 plumes in homogeneous fire outflow regions. Most importantly, they are the only flights

2 where the P-3B penetrated the pyroCu clouds of active fire plumes. In this study, we em-

3 phasize data obtained with a multi-wavelength scanning radiometer, NASA's Cloud Ab-

4 Sorption Radiometer (CAR; Gatebe et al., 2003; King et al., 1986), which provides unpre-

5 cedented detail on pyroCu clouds.

The CAR instrument measures scattered light in 14 spectral bands between 0.34 and

$72.30 \mu \mathrm{m}$ and has a unique scanning geometry and is able to scan a scene of the atmosphere

8 and surface over a $190^{\circ}$ scan angle and at high angular resolution ( $1^{\circ}$ instantaneous field of

9 view). When it is flown inside clouds, it is able to provide a side view in the zenith and na-

10 dir directions, and all scattering angles in between from an aircraft platform with as much

11 as a $5^{\circ}$ roll-assuming no aircraft pitch. Data are sampled simultaneously and continuously

12 on nine individual detectors. Eight of the data channels for spectral bands from 0.34 to 1.27

$13 \mu \mathrm{m}$ are always registered during the operation, while the ninth data channel is registered for

14 signal selected among six spectral channels $(1.55-2.30 \mu \mathrm{m})$ on a filter wheel. The filter

15 wheel can either cycle through all six spectral bands at a prescribed interval (usually chan-

16 ging filter every fifth scan line), or lock onto any one of the six spectral bands, mostly

$171.656,2.103$, or $2.205 \mu \mathrm{m}$, and sample it continuously

\section{Observational Assessment of the PyroCu}

Some of the biggest Saskatchewan fires during the 2008 summer ARCTAS campaign burned west of Mcintosh Lake and east of Lake Athabaska in Canada. On 2 July (P-3 Flight \#18/CAR Flight \#2017) and 6 July (P-3 Flight \#20/CAR Flight \# 2019) the conditions for fres seemed right, as a cold front moved over the region setting up conditions conducive to sending hot smoke plumes billowing into the upper atmosphere. The P-3B aircraft, with its suite of instruments, was in the air and managed to acquire very good fire data. Below, we provide a general description of the 2 July flight and the primary instruments that were op- 
1 erating during the flight. We will not describe the 6 July flight because of similarities be-

2 tween the two flights, however, full details for this flight can be found on the CAR website

3 (http:/car.gsfc.nasa.gov/data/index.phpid=115\&mis id =8\&n=ARCTAS). Through these

4 descriptions, we attempt to paint a picture of the nature and character of the fires and in ad-

5 dition, create a preamble for further work on pyroCu and their effects on climate.

62.1 General Description of Flight 2017, 2 July 2008

7 Our objectives for this flight included flying a segment under the Terra satellite, co-

8 ordinated with the NASA B-200 carrying the High Spectral Resolution Lidar (HSRL) and

9 the Research Scanning Polarimeter (RSP) instrument) with radiation measurements under

10 clear sky conditions stacked at different altitudes, and in situ observations of flaming fires,

11 showing plume evolution and vertical profiles in homogeneous fire outflow regions. The

12 flight took 6 hours and 20 minutes, with take off at 15:31 UTC (9:31 a.m. local time; see

13 flight log: http:/car.gsfc.nasa.gov/data/index.php?id=113\&mis_id=8\&n=ARCTAS). Fig.

14 la shows the flight path from Cold Lake, heading northeast towards Reindeer Lake. We

15 made measurements collocated with the B-200 for about 50 minutes beginning at 16:25

16 UTC, and observed active fires of different intensities under scattered cloud conditions. We

17 penetrated an active fire plume near Mcintosh Lake at two altitudes, 1303 m (19:18 UTC)

18 and $294 \mathrm{~m}$ (19:49 UTC) above the local surface, and flew along the plume axis for about 80

$19 \mathrm{~km}$ to study the evolution of aerosol microphysics during downwind transport. Between the

20 two penetrations, we obtained radiation measurements in a vertical profile in the most

21 homogeneous part of the plume and flew across-plume at a low-level. We also sampled

22 outflow from a pyroCu cloud and penetrated the cloud to sample the inside. Fig. Ib shows

23 an image taken by the Moderate Resolution Imaging Spectroradiometer (MODIS) flying

24 aboard the Aqua satellite at 19:35 UTC over the region highlighted in the white box in Fig.

25 Ia. The cloud fields seen in the satellite image are most likely associated with the active 
1 fires in the region. Note that the green squares represent fire locations detected by MODIS 2 on the Terra satellite, taken during the overpass earlier that day, at 17:55 UTC. The red 3 squares represent fire locations based on high radiance, relative to background, as seen with 4 the MODIS/Aqua 4-um channel during the overpass (e.g. Giglio, 2003).

Figs. 1c and 1d show CAR quicklook images selected from a section of the flight where the aircraft went through a pyroCu core during the flight of 2 July (the green line

7 highlights the flight path through the pyroCu, whereas the orange dot in Fig. $1 \mathrm{~b}$ marks the 8 location of the plume core). A combination of different CAR bands representing red, 9 green, and blue colors helps to differentiate between clouds and smoke and to see through 10 smoke, revealing land surface features such as green vegetation and dark water bodies (see 11 Fig. 1c: false-color $\operatorname{RGB}(0.47,0.38,0.34) \mu \mathrm{m}$; Fig 1d: false-color $\operatorname{RGB}(1.66,1.04,0.38)$ $12 \mu \mathrm{m})$. As shown in Fig. 1d, the fire was widespread, covering hundreds of hectares, and it 13 took the aircraft $\sim 15$ seconds to cross the core (the core covers a ground area $\sim 2 \mathrm{~km}$, where 14 the measured aircraft groundspeed varied between $127 \mathrm{~ms}^{-1}$ and $138 \mathrm{~ms}^{-1}$ ). The aircraft 15 altitude changed dramatically while traversing the core, rising by $93 \mathrm{~m}$, from $2747 \mathrm{~m}$ to $2840 \mathrm{~m}$ above mean sea level, an indication of strong updrafts $>8 \mathrm{~ms}^{-1}$. The height of the 2 July PyroCu top above ground was $>3000 \mathrm{~m}$, and the boundary layer (BL) height at the fire location and time of aircraft data acquisition was $1976 \mathrm{~m}$. The $19 \mathrm{BL}$ was obtained by interpolating the values for 12 noon and $3 \mathrm{pm}$ local times from the 20 NASA Goddard Earth Observing System (GEOS-5) data provided by the Global Modelling 21 and Assimilation Office (GMAO). Therefore, the pyroCu extended well above the boun22 dary layer. Recent studies based on digitized plume height analysis from the Multi-angle 23 Imaging SpectroRadiometer (MISR) instrument aboard the Terra satellite have shown that 24 of order $10 \%$ of the plumes are injected higher than $0.5 \mathrm{~km}$ above the BL; out of eight 
1 study area) are typically injected the highest, with a median injection top height of $\sim 1200 \mathrm{~m}$

2 (as compared to $\sim 800 \mathrm{~m}$ for croplands; Kahn et al., 2008; Val Martin et al., 2010). Those

3 studies also found a correlation between the plume injection height and fire radiative power

4 (FRP) measurements from MODIS (Ichoku et al., 2008), indicating that in addition to at5 mospheric stability structure, fire intensity (represented by FRP) has a strong influence on 6 plume injection height; plume top heights that reached the free troposphere (FT) were pro7 duced mainly by high intensity fires having a median FRP of order $500 \mathrm{MW}$. Table 1

8 shows the FRP values of the MODIS fire pixels (depicting their relative intensities) from 9 Aqua coinciding with 2 July 2008 flights (in space but not in time). The FRP data record 10 corresponding spatially to the pyroCu plume penetrated by $\mathrm{P}-3 \mathrm{~B}$ is shown in boldface char11 acters. However, because of the large difference in time between the FRP measurement 12 from Aqua-MODIS (19:35 UTC) and P-3B penetration of the pyroCu ( $21: 05$ UTC), this 13 FRP value is much less than what would have been required to generate such a high plume 14 and the associated pyroCu. It is probable that the fire became much stronger by the time of 15 the pyroCu measurement. For the P-3B pyroCu penetration on 6 July 2008 , no fire pixels 16 were detected by MODIS within a few $\mathrm{km}$ of the pyroCu. It is believed that the pyroCu 17 may have moved substantially away from the fire at the time of its penetration, making it 18 impossible to link it to any specific fire detected by MODIS. Therefore, to establish a cause 19 and effect relationship of such transient features as fires and their associated plumes and 20 pyro $\mathrm{Cu}$, it is crucial to conduct airborne measurements in synchronicity with satellite over21 passes and ground-based measurements whenever possible.

222.2 NASA P-3B Payload during ARCTAS 2008

23 Fig. 2a shows the platform we used in this campaign, the NASA P-3B aircraft. The 24 picture was taken at NASA Ames on 24 June 2008 just before a transit nlight to Cold Lake, 25 Canada at the start of the ARCTAS summer campaign. The P-3B payload included 10 pri- 
1 mary instruments (see Table 2) for measuring aerosol optical depth, aerosol extinction and 2 scattering, aerosol size distribution (Russell et al., 1999; Clarke et al., 2007), spectral (0.380

$3-2.200 \mu \mathrm{m})$ and broadband downwelling and upwelling solar $(0.2-3.6 \mu \mathrm{m})$, and IR irradi-

4 ance $(4.5-42 \mu \mathrm{m}$; Pilewskie et al., 2003; Bucholtz personal communication:

$5 \mathrm{http} / /$ airbornescience.nasa.gov/instrument/BBR), angular distribution of scattered radiation

6 in different directions (Gatebe et al., 2003), cloud condensation nuclei (Roberts and Nenes,

7 2005; Lance et al., 2006), and $\mathrm{NO}_{2}$ and carbon monoxide (Strawa et al., 2007; Provencal et

8 al. 2005). The base meteorological and navigational measurements were provided by the

9 Project Data System, which is the primary navigational data system for P-3B investigators.

10 Fig. 2b shows a schematic of the CAR instrument (Gatebe et al., 2003; King et al.,

11 1986), highlighting its main features. Fig. 2c shows a pyroCu taken onboard the NASA P-

$123 \mathrm{~B}$ on 2 July 2008 near Reindeer Lake, Saskatchewan, Canada. The aircraft flew around

13 these fires, sampling clean air upwind and the polluted air downwind. It then flew through

14 the smoke at various altitudes, probing and charting changes in concentration and the

15 "chemical evolution" of the compounds emitted by the fires. The plane also flew into the

16 "core" of the rising fire plumes, where the CAR instrument managed to acquire good data

17 as discussed in this study. These represent the first such measurements in the core of a

18 pyroCb of which we are aware. (See pictures from the 2 July flight on the CAR website at

19 http:/car.gsfc.nasa.gov/data/photos.php?mis id=8\&n=ARCTAS\&d=2008-07.

$20 \quad 02 \& \mathrm{f}=2017 \& \mathrm{l}=\mathrm{h}$ and from the 6 July flight at

21 http:/car.gsfc.nasa.gov/data/photos.php?mis_id=8\&n=ARCTAS\&d=2008-07-

$2206 \& f=2019 \& 1=h$.

23 In the next section, we will present an analysis of the CAR measurements inside

24 pyroCu and results from a Monte Carlo simulation of the radiation field within optically

25 dense media analogous to those observed above. 


\section{Results and Discussion}

23.1 Analysis of CAR Measurements

The core of the pyroCu as seen in Figs. 1c and $1 \mathrm{~d}$ stands out as a very dark region of

4 the plume, where radiation seems to be uniformly distributed and dominated by strong ab-

5 sorption in all directions. The CAR instrument measured very low spectral radiance values

$6\left(<1 \mathrm{Wm}^{-2} \mu \mathrm{m}^{-1} \mathrm{sr}^{-1}\right.$ in the ultraviolet and visible bands having $\lambda<0.5 \mu \mathrm{m}$, and at $\lambda=1.6$

$7 \mu \mathrm{m}$, and 2-5 $\mathrm{Wm}^{-2} \mu \mathrm{m}^{-1} \mathrm{Sr}^{-1}$ for bands between $0.5 \mu \mathrm{m}$ and $1.3 \mu \mathrm{m}$ ), independent of direc-

8 tion. The radiance distributions within the core at two zenith angles: $5^{\circ}$ and $175^{\circ}$ at 0.472

$9 \mu \mathrm{m}$, shown in Fig. 3 demonstrate that there is hardly any difference between the downwel-

10 ling and upwelling radiance within the core region. The $a, b$ and $c$ images in this figures

11 were taken by a forward camera aboard the NASA P-3B at the entry, core, and exit points

12 in the pyroCu. Note the brownish color of the plume inside the core region. The radiance

13 decreases by about two orders of magnitude from outside to the central part of the core, ir-

14 respective of the direction and wavelength. We speculate that the core region plays an im-

15 portant role as the main physical pathway through which emissions from fires are trans-

16 ported into the upper troposphere/lower stratosphere (UT/LS), but this observation needs to

17 be validated.

18 Fig. 4 compares relative spectral radiance as a function of zenith angle for internally

19 scattered radiation measured deep inside an optically thick water cloud, pyrocu and a thick

20 "pure" smoke, which is defined by lack of reflectance sensitivity in the near-infrared bands

$21(\lambda \geq 0.87 \mu \mathrm{m})$, at selected CAR wavelengths. According to King et al. (1990), radiance

22 measurements from an individual scan of the CAR are considered to be in the diffusion

23 domain, if three conditions are satisfied: (i) the zenith radiance exceeds the nadir radiance,

24 (ii) the maximum deviation from the theoretical cosine curve is less than or equal to $5 \%$ of

25 the mean amplitude, and (iii) the number of times the deviations from a cosine distribution 
1 changes sign is greater than or equal to 4 , which helps to assure that fluctuations are ran-

2 dom, and not systematic drifts. These criteria pertain to the diffusion domain of an optically

3 thick media if the scattering is conservative (no absorption), and thus are to be expected for

4 liquid water clouds at wavelengths around $0.67 \mu \mathrm{m}$ (as seen in Fig. 4a). The theoretical

5 curve is generated from measured zenith and nadir radiances using the following cosine 6 relationship

$7 \quad I(\tau, \cos \theta)=a+b \cos \theta$

8 where

where

$$
\begin{aligned}
& a=\frac{1}{2}\left(I_{0}(\tau, 1)+I_{180}(\tau,-1)\right), \\
& b=\frac{1}{2}\left(I_{0}(\tau, 1)-I_{180}(\tau,-1)\right)
\end{aligned}
$$

and $I_{0}$ and $I_{180}$ are the zenith and nadir radiances at $\theta=0^{\circ}$ and $\theta=180^{\circ}$, respectively. From Eq. Ia, we came up with a general equation for any two downward and upward viewing 13 angles in the form

$$
\begin{aligned}
& a=\frac{1}{2}\left(I_{\theta^{\prime}}\left(\tau, \cos \theta^{\prime}\right)+I_{180-\theta^{\prime}}\left(\tau,-\cos \theta^{\prime}\right)\right), \\
& b=\frac{1}{2 \cos \theta^{\prime}}\left(I_{\theta^{\prime}}\left(\tau, \cos \theta^{\prime}\right)-I_{180-\theta^{\prime}}\left(\tau,-\cos \theta^{\prime}\right)\right)
\end{aligned}
$$

As such, Eq. $1 \mathrm{~b}$ is not restricted to using zenith $\left(\theta=\theta^{\prime}=0^{\circ}\right)$ and nadir $\left(\theta=\theta^{\prime}=180^{\circ}\right)$ input radiances, unlike Eq. Ia, and can be used to describe the radiation field in optically thick media given any two downward and upward viewing directions, or $\theta^{\prime}=90^{\circ}$ (where $\mathrm{b}$ $\left.=I_{\infty}(\tau)\right)$ and any other direction. This general formula can be applied to CAR observations away from the zenith and nadir directions, and therefore can accommodate the realities of data acquisition on an airborne platform that has a nonzero pitch and/or roll angle.

For the liquid water cloud case, obtained on 29 June 2008 (20:00 UTC) in Canada, the angular radiance field at the shortest wavelengths can be described by a cosine function 24 expected for conservative scattering in the diffusion domain (King, 1981; King et al. 25 1990), where the cloud is expected to have a small to negligible amount of absorption. This 
1 is demonstrated in Fig. 5 (liquid water cloud case), where the angular distribution of the

2 radiation field obtained from measurements (continuous curve, abstracted from Fig. 4 a) is

3 compared to that expected in the diffusion domain for conservative scattering (dotted

4 curve) at $\lambda=0.472 \mu \mathrm{m}$. We note that the angular radiance field becomes increasingly ani-

5 sotropic as absorption increases in the CAR bands at wavelengths exceeding $1 \mu \mathrm{m}$ (Fig.

64 a), because stronger absorption implies that a smaller portion of downwelling solar radi-

7 ation can be reflected back up from below. In this case, the three conditions for the diffu-

8 sion domain at a conservative scattering wavelength were met. King et al., (1990) show that

9 when the three conditions are assured, quantitative information about cloud absorption

10 properties from the angular distribution of scattered radiation can be derived, dependent

11 only on the optical properties of the medium and possibly on the reflectivity of the under-

12 lying surface, but independent of the solar zenith angle and solar irradiance.

13 The problem now is to describe the radiation pattern inside an optically thick pyroCu,

14 the core of a pyrcoCu, and smoke, which seem to be increasingly anisotropic as absorption

15 tends to dominate at the shorter wavelength and is not negligible. However, the diffusion

16 domain theory for optically thick clouds with modified $a$ and $b$ (Eq. 1b; Fig 4b), can also

17 describe the angular radiance distribution in a pyroCu as shown in Fig. 5 (blue solid curve

18 represents measurements, green dotted line represents the fit), but $b$ must assume a negative

19 value, because in this case, the relative radiance is highest at nadir rather than at zenith. The

20 cosine function can also represent the pyroCu core case (Fig. 4c), but an additional $\sin \theta$

21 term is needed (Eq. 2) to reproduce the bow shaped curves in Figs. 4c and 5 (note that the

22 solid lines represent observations, while dotted lines represent fit to the observations).

$23 \quad I(\tau, \cos \theta)=(a+b \cos \theta)+(c+d \sin \theta)$

24 which requires only the knowledge of the zenith angle, $\theta$, and some constants. The param-

25 eters $a$ and $b$ are easily determined from Eq. Ia \& 1b. The last two terms represent a math- 
1 ematical ansatz, where the term $c$ is obtained from zenith and nadir radiances following Eq.

$2 \mathrm{lb}$, and $d$ was determined through trial and error until the best fit was found $(d=-0.1)$. It

3 is interesting to see that radiation transport in an optically thick pyroCu core can be de-

4 scribed by simple geometrical functions, whereby the first two terms represent scattering

5 processes, while the third and fourth terms represent absorption processes. To gain better

6 understanding of radiation transport in a pyro $\mathrm{Cu}$, we next attempt to reproduce the radiation

7 pattern observed by the CAR instrument using $1 \mathrm{D}$ and 3D Monte Carlo simulations.

\subsection{Monte Carlo Simulation}

9 We now explore the optical characteristics of pyroCu using 1D and 3D Monte Carlo 10 radiative transfer simulations. The Monte Carlo model is an appropriately modified version 11 of the code used in several earlier studies, including Várnai and Marshak (2001), and was 12 also tested in the Intercomparison of 3D Radiation Codes (I3RC) project (Cahalan et al., 13 2005). The actual code used in this paper was also tested through comparisons with 14 DISORT (Discrete Ordinates Radiative Transfer) model (Stamnes et al. 1988) runs for ab15 sorbing, plane-parallel clouds. To keep simulation uncertainties below $0.5 \%$, each result is 16 based on 4 million photon trajectories in backward Monte Carlo simulations.

17 Because the purpose of these Monte Carlo simulations is to understand the basic be18 haviours in Fig. 4 (and not to simulate the exact values observed by CAR), the simulations 19 use a simple setup (Fig. 6). The calculations assume a 2D slab cloud that is infinite in the 20 cross-sun $(\mathrm{Y})$ direction, lies between $1 \mathrm{~km}$ and $2 \mathrm{~km}$ altitudes, and is $1 \mathrm{~km}$ wide $(\Delta \mathrm{Z}=\Delta \mathrm{X}$

$21=1 \mathrm{~km}$ ). The extinction coefficient is $100 \mathrm{~km}^{-1}$, so the cloud optical thickness is 100 in 22 both $\mathrm{Z}$ and $\mathrm{X}$ directions. Because we simulate radiances deep inside the cloud, where 23 multiple scattering minimizes the details of the scattering phase function, we assume the 24 cloud particles have a Henyey-Greenstein phase function with an asymmetry parameter of $\mathrm{g}$ $25=0.85$. The solar zenith angle is taken as $30^{\circ}$ and the surface albedo as 0.2 . For simplicity, 
1 no atmospheric effects-Rayleigh scattering or gaseous absorption-are considered.

Fig. 7 shows simulation results that can shed light onto the behaviours in Figs. $4 a, 4 b$,

3 and $4 \mathrm{c}$. (At this stage we do not attempt to simulate the complex behaviours in Fig. 4d.)

4 The black dashed line displays a qualitatively similar behaviour to the clean cloud in Fig.

54 a and shows the general behaviour of 1D radiation calculations, which assume horizon-

6 tally homogeneous and infinite (plane-parallel) clouds. The line illustrates that in ID cases,

7 the radiance of the highly diffuse radiation deep inside clouds is always greater looking up

8 than looking down regardless of the amount of particle absorption. This is because the con-

9 servation of energy and the lack of light sources below imply that the upwelling flux can

10 never exceed the downwelling flux. This particular simulation was based on a single scat-

11 tering albedo of 0.975 , representing stronger absorption than typically occur in liquid water

12 clouds in the visible near-infrared (cf. Fig. 4a), but with a shape typical of what occurs in

13 absorbing liquid water clouds.

14 The other three curves in Fig. 7 are from 3D simulations. Energy conservation re-

15 quires the scene average net radiation to flow downward even in 3D situations. However,

16 this trend can reverse locally inside clouds in 3D situations because large amounts of radi-

17 ation can reach the surface easily in clear areas between clouds and, after reflection from

18 the surface, can enter through the cloud base and create an upwelling flow of radiation in-

19 side the cloud. In addition, sunlight entering through a sunlit cloud side can create a hori-

20 zontal net flow toward the shadowy side (Fig. 6).

21 The blue squares in Fig. 7 show that the downward flow entering through the cloud

22 top still dominates our 3D case if there is no absorption. The red circles, however, show

23 that absorption can drastically change the radiation pattern by depleting much of the

24 downwelling radiation wending its way through the cloud. As a result, the upwelling flow

25 of radiation reflected from the surface can match the weakened downwelling flow, creating 
1 comparable intensity peaks looking up $\left(\theta=0^{\circ}\right)$ and down $\left(\theta=180^{\circ}\right)$. This is similar to the

2 behaviour in Fig. 4c (pyroCu core). Lastly, the green dashed curve in Fig. 7 shows that for

3 a lower altitude cloud absorption reduces the downwelling (upwelling) radiation more

4 (less), and so upwelling radiation can fully dominate and create a trend similar to that in

5 Figure $4 b($ pyroCu).

6 Finally, Fig. 8 more explicitly explores the role of absorption and scattering proper-

7 ties in shaping radiation patierns. Fig.8a shows that even relatively weak absorption (SSA $\leq$

80.99 ) can allow upwelling radiation to match or even exceed the downwelling flow in a $3 \mathrm{D}$

9 situation. In turn, Fig. $8 \mathrm{~b}$ shows that increasing the number of particles (i.e., the extinction

10 coefficient) yields similar effects to increasing their absorptivity, as both changes make it

11 harder for radiation to reach an instrument deep inside the cloud. This implies that radiation

12 patterns similar to those observed in pyroCu and pyroCu core (Figs. $4 \mathrm{~b}$ and $4 \mathrm{c}$ ) can arise in

13 thick clouds even if absorption is relatively weak, although stronger absorption is required

14 in thin clouds. The interplay between scattering and absorption can also allow upwelling

15 radiation to dominate even in the upper parts of clouds if particles are distributed unevenly.

16 For example, if the cloud extinction coefficient increases with altitude (e.g., Raga and

17 Jonas, 1993)-e.g., as ascending droplets grow through condensation-strong absorption or

18 scattering above can greatly reduce the downwelling radiation and allow the upwelling ra-

19 diation reflected from the ground to dominate even at high altitudes.

\section{Conclusions}

This study provides an analysis of airborne radiation measurements with the CAR instrument within strong pyroCu over boreal forest fires in Saskatchewan, Canada during the Arctic Research of the Composition of the Troposphere from Aircraft and Satelltes (ARCTAS) summer fleld campaign in 2008. 
We found the pyroCu core to be very interesting having very low light levels from the

2 UV to near IR regions of the electromagnetic spectrum, and very uniform radiance field in

3 all directions. Spectral radiances measured within the core were very small $<1 \mathrm{Wm}^{-2} \mathrm{~mm}^{-}$

$4{ }^{1} \mathrm{sr}^{-1}$ in the ultraviolet and visible bands, $\lambda<0.5 \mu \mathrm{m}$, and at $\lambda=1.6 \mu \mathrm{m}$, but substantially lar-

5 ger $\left(2-5 \mathrm{Wm}^{-2} \mu \mathrm{m}^{-1} \mathrm{sr}^{-1}\right)$ for $0.5 \mu \mathrm{m}<\lambda<1.3 \mu \mathrm{m}$, independent of direction. We found the

6 angular distribution of radiance within the pyroCu to be related to the diffusion domain in

7 water clouds that can be described by very similar cosine functions with an additional sine

8 term. We demonstrate with Monte Carlo simulation that radiation transport in pyroCu is

9 inherently a 3D problem and must account for strong particle absorption. The proposed

10 simple description of the radiation distribution within the pyroCu or pyroCu core may lead

11 to better understanding of these cloud systems and provide a simpler solution for their in-

12 clusion in climate models. Based on the low radiation values measured in the core of the

13 pyroCu, we speculate that the formation of the dark core is an important feature for estab-

14 lishment of a possible pathway for transportation of fire emissions to the upper troposphere

15 and lower stratosphere, but this remains to be validated.

16 Acknowledgements

17 This research was supported by the Science Mission Directorate of the National 18 Aeronautics and Space Administration as part of the Radiation Sciences Program under Hal

19 B. Maring and Airbome Science Program under Bruce Tagg. We also thank F. Ewald, P.

20 Kundu, R. A. Marshak, W. Wiscombe, A. Nenes, and T. Lathem for insightful discussions

21 and comments. This work was performed under NASA Grants NNX08A89G and 22 NNX11AQ98G.

\section{References}

24 Barnick, J. D., Aknan, A. A., 2008. P.3B Supporting Measurements Data System (PDS): 
htp.//ww.espo.nasa.gov/arctas/does/instruments/pds.pdi

2 Cahalan R.F., Oreopoulos, L., Marshak, A., Evans, K.F., Davis, A., Pincus, R., Yetzer, K., M., Kassianov, E., Kinne, S., Macke, A., OHirok W., Partain, P., Prigarin, S., Rublev, A., Stephens, G., Szczap, F., Takara, E., Várnai, T., Wen, G., Zhuravleva, T., 2005. The International Intercomparison of 3D Radiation Codes (I3RC): Bringing together the most advanced radiative transfer tools for cloudy atmospheres, Bull. Amer. Meteor. Soc., 86, 1275-1293.

Clarke, A., McNaughton, C., Kapustin, V., Shinozuka, Y., Howell, S., Dibb, J., Zhou, J., Anderson, B., Brekhovskikh, V., Turner, H., Pinkerton, M., 2007. Biomass burning and pollution aerosol over North America: Organic components and their influence on spectral optical properties and humidification response, J. Geophys. Res., 112 , D12S18, doi: $10.1029 / 2006.10007777$.

Damoah, R., Spichtinger, N., Servranckx, R., Fromm, M., Eloranta, E.W., Razenkov, I.A., James, P., Shulski, M., Forster, C., Stohl, A., 2006. A case study of pyro-convection using transport model and remote sensing data, Atmos. Chem. Phys., 6, 173-185.

Fromm, M., Lindsey, D.T., Servranckx, R., Yue, G., Trickl, T., Sica, R., Doucet, P., GodinBeekmann, S., 2010. The untold story of pyrocumulonimbus, Bull. Ameri. Meteor. Soc., $91,1193-1209$.

Fromm, M., Bevilacqua, R., Servranckx, R., Rosen, J., Thayer, J, Herman, J., Larko, D., Servranckx, R., 2005. Pyro-cumulonimbus injection of smoke to the stratosphere: Observations and impact of a super blowup in northwestern Canada on 3-4 August 1998, J. Geophys. Res., 110, D08205, doi:10.1029/2004JD005350.

Fromm, M. Servranckx, R., 2003. Transport of forest fire smoke above the tropopause by supercell convection, Geophys. Res. Lett., 30, 1542, doi:10.1029/2002GL016820. 
Gatebe, C.K., King, M.D., Platnick, S., Arnold, G.T., Vermote, E.F., Schmid, B., 2003.

Airborne spectral measurements of surface-atmosphere anisotropy for several surfaces and ecosystems over southern Africa, J. Geophys. Res., 108, 8489, doi:10.1029/2002JD002397.

Giglio, L., Descloitres, J., Justice, C., Kaufman, Y., 2003. An enhanced contextual fire detection algorithm for MODIS. Remote Sens. Environ., 87, 273- 282.

Howell, S.G., Clarke, A.D., Shinozuka, Y., Kapustin, V., McNaughton, C.S., Huebert, B.J., Doherty, S.J., Anderson, T.L., 2006. Influence of relative humidity upon pollution and dust during ACE-Asia: Size distributions and implications for optical properties, J. Geophys. Res. 111, D06205, doi:10.1029/2004JD005759.

Ichoku, C., Giglio, L., Wooster, M.J., Remer, L.A., 2008. Global characterization of biomass-burning patterns using satellite measurements of Fire Radiative Energy, Remote Sens. Environ., 112, 2950-2962.

Jacob, D.J., Crawford, J.H., Maring, H., Clarke, A.D., Dibb, J.E., Emmons, L.K., Ferrare, R.A., Hostetler, C.A., Russell, P.B., Singh, H.B., Thompson, A.M., Shaw, G.E., McCauley, E., Pederson, J.R., Fisher, J.A., 2010. The Arctic Research of the Composition of the Troposphere from Aircraft and Satellites (ARCTAS) mission: design, execution, and first results. Atmos. Chem. Phys., 10, 5191-5212.

Kahn, R.A., Chen, Y., Nelson, D.L., Leung, F.Y., Li, Q.B., Diner, D.J., Logan, J.A., 2008. Wildire smoke injection heights: two perspectives from space, Geophys. Res. Lett., 35, L04809, doi:10.1029/2007GL032165.

King, M.D., Radke, L.F., Hobbs, P.V., 1990. Determination of the spectral absorption of solar radiation by marine stratocumulus clouds from airborne measurements within clouds, J. Atmos. Sci., 47, 894-907.

King, M.D., Strange, M.G., Leone, P., Blaine, L.R., 1986. Multiwavelength scanning radi- 
ometer for airborne measurements of scattered radiation within clouds, J. Atmos. Oceanic Technol. 3, 513-522.

King, M.D., 1981. A method for determining the single scattering albedo of clouds through observation of the internal scattered radiation field, J. Atmos. Sci., 38, 2031-2044.

Luderer, G., Trentmann, J., Winterrath, T., Textor, C., Herzog, M., Graf, H.-F., Andreae, M.O., 2006. Modeling of biomass smoke injection into the lower stratosphere (part II): sensitivity studies, Atmos. Chem. Phys., 6, 5261-5277.

McCarter, R.J., Broido, A., 1965. Radiative and convective energy from wood crib fires, Pyrodyn., 2, 65-85.

Packham, D.R., 1969. Heat transfer above a small ground fire, Australia Forest Research 5, $19-24$.

Pilewskie, P., Pommier, J., Bergstrom, R., Gore, W., Howard, S., Rabbette, M., Schmid, B., Hobbs, P.V., Tsay, S.C., 2003. Solar spectral radiative forcing during the Southern African Regional Science Initiative, J. Geophys. Res., 108, 8486, doi:10.1029/2002JD002411.

Provencal, R., Gupta, M., Owano, T.G, Baer, D.S, Ricci, K.N, O'Keefe, A., Podolske, J.R, 2005. Cavity-enhanced quantum-cascade laser-based instrument for carbon monoxide measurements, Appl. Opt., 44, 6712-6717.

Raga, G.B., Jonas, P.R., 1993. Microphysical and radiative properties of small cumulus clouds over the sea, Quart. J. Royal Meteor. Soc., 119, 1399-1417.

Roberts, G., Nenes, A., 2005. A continuous flow streamwise thermal-gradient CCN chamber for atmospheric measurements, Acrosol Sci. Technol., 39, 206-221.

Russell, P.B., Livingston, J.M., Hignet, P., Kinne, S., Wong, J., Hobbs, P.V., 1999. Aerosol-induced radiative flux changes off the United States Mid-Atantic coast: comparison of values calculated from sumphotometer and in situ data with those measured by 
airborne pyranometer, J. Geophys. Res., 104, 2289-2307.

Shinozuka, Y., Redemann, J., Livingston, J.M., Russell, P.B., Clarke, A.D., Howell, S.G., Freitag, S., O’Neill, N.T., Reid, E.A., Johnson, R., Ramachandran, S., McNaughton, C. S., Kapustin, V.N., Brekhovskikh, V., Holben, B.N., McArthur, L.J.B., 2011 . Airborne observation of aerosol optical depth during ARCTAS: vertical profiles, intercomparison and fine-mode fraction, Atmos. Chem. Phys., 11, 3673-3688.

Soja, A.J., Tchebakova, N.M., French, N.H.F., Flannigan, M.D., Shugart, H.H., Stocks, B.J., Sukhinin, A.I., Parfenova, E.I., Chapin, F.S., Stackhouse, P.W., 2007. Climateinduced boreal forest change: predictions versus current observations, Global and Planet. Change, 56, 274-296.

Stamnes, K., Tsay, S.-C., Wiscombe, W., Jayaweera, K., 1988, Numerically stable algorithm for discrete-ordinate-method radiative transfer in multiple scattering and emitting layered media, Appl. Opt., 27, 2502-2509.

Stocks, B.J., 1995. The extent and impact of forest fires in northern circumpolar countries. In: Levine, J.S. (Ed.), Global Biomass Burning: Atmospheric, Climatic, and Biospheric Implications, MIT Press, Cambridge, Massachusetts, pp. 197-202.

Stocks, B.J., Mason, J.A., Todd, J.B., Bosch, E.M., Wotton, B.M., Amiro, B.D., Flannigan, M.D., Hirsch, K.G., Logan, K.A., Martell, D. L., Skinner, W.R., 2003. Large forest fires in Canada, 1959-1997. J. Geophys. Res. 108, 8149, doi: 10.1029/2001JD000484.

Strawa, A.W., Provencal, R., Owano, T., Kirschstetter, T.W., Hallar, G., Williams, M.B., 2007. Aero3X: Fast, accurate measurement of aerosol optical properties for climate and air quality studies, American Geophysical Union, Fall Meeting 2007, abstract \#A53G-03 (http:/adsabs.harvard.edu/abs/2007AGUFM.A53G.03S).

Trentmann, J., Luderer, G., Winterrath, T., Fromm, M., Servranckx, R., Textor, C., Herzog, M., Andreae, M.O., 2006. Modeling of biomass smoke injection into the lower strato- 
sphere by a large forest fire (Part 1): reference study, Atmos. Chem. Phys., 6, 5247$2 \quad 5260$.

3 Val Martin, M., Logan, J.A., Kahn, R.A., Leung, F.-Y., Nelson, D.L., Diner, D.J., 2010.

4 Smoke injection heights from fires in North America: analysis of 5 years of satellite 5 observations, Atmos. Chem. Phys., 10, 1491-1510.

6 Varnai, T., Marshak, A., 2001. Statistical analysis of the uncertainties in cloud optical depth

7 retrievals caused by three-dimensional radiative effects, J. Atmos. Sci., 58, 1540-1548.

8 Wooster, M.J., 2002. Small-scale experimental testing of fire radiative energy for quantify9 ing mass combusted in natural vegetation fires, Geophys. Res. Lett., 29, $10 \quad$ doi:10.1029/2002GL015487.

11 Wooster, M.J., Roberts, G., Perry, G.L. W., Kaufman, Y.J., 2005. Retrieval of biomass 12 combustion rates and totals from fire radiative power observations: FRP derivation and 13 calibration relationships between biomass consumption and fire radiative energy re14 lease, J. Geophys. Res., 110, D24311, doi: 10.1029/2005JD006318. 
1 Table 1

2 Locations and FRP values of fire pixels detected by Aqua-MODIS on 2 July 2008 at 19:35

3 UTC in the vicinity of the measured pyroCu, as indicated in Fig. 1b

\begin{tabular}{lll}
\hline $\begin{array}{l}\text { Latitude } \\
(\mathrm{N})\end{array}$ & $\begin{array}{c}\text { Longitude } \\
(\mathrm{W})\end{array}$ & $\begin{array}{l}\text { Fire Radiative Power } \\
(\mathrm{MW})\end{array}$ \\
\hline 55.685 & 105.283 & 108.273 \\
55.682 & 105.299 & 112.081 \\
55.677 & 105.331 & 37.455 \\
55.688 & 105.320 & 84.818 \\
55.706 & 105.320 & $\mathbf{1 0 5 . 7 1 0}$ \\
55.733 & 105.334 & 20.674 \\
55.778 & 105.235 & 24.367 \\
55.773 & 105.267 & 18.737 \\
55.803 & 105.197 & 84.151 \\
55.838 & 105.150 & 25.296 \\
55.835 & 105.166 & 17.619 \\
\hline
\end{tabular}


Table 2

P.3B Aircraft Instrumentation for ARCTAS

\begin{tabular}{|c|c|c|c|c|}
\hline Instrument Name & Data Products & Technique & $\begin{array}{c}\text { Principal } \\
\text { Investigator }\end{array}$ & $\begin{array}{c}\text { Detection limit } \\
\text { (Nominal accuracy) }\end{array}$ \\
\hline AERO3X & $\begin{array}{l}\text { Aerosol optical prop- } \\
\text { erties, } \mathrm{NO}_{2} \text { mixing } \\
\text { ratio }\end{array}$ & $\begin{array}{l}\text { Cavity ring-down ex- } \\
\text { tinction; Sample rate: } \\
2 \text { sec. (Strawa et al., } \\
\text { 2007). }\end{array}$ & $\begin{array}{l}\text { A. Strawa, NASA } \\
\text { ARC }\end{array}$ & $\begin{array}{l}\text { Extinction and scattering }-2 \sigma \\
\text { sensitivity } \approx 0.2 \mathrm{Mm}^{-1}, \text { Extinction } \\
\text { and scattering }-2 \sigma \text { precision } \approx \\
0.1 \mathrm{Mm}^{-1}, \mathrm{NO}_{2} \text { mixing ratio }-2 \sigma \\
\text { sensitivity better than } 1 \mathrm{ppb}\end{array}$ \\
\hline $\begin{array}{l}\text { Ames Airborne } \\
\text { Tracking Sunpho- } \\
\text { tometer (AATS) }\end{array}$ & $\begin{array}{l}\text { Aerosol optical depth } \\
\text { and extinction, } \\
\text { water vapor column } \\
\text { and profile }\end{array}$ & $\begin{array}{l}\text { Tracking Sun photom- } \\
\text { eter, } 0.354-2.138 \mu \mathrm{m} \\
\text { (Russell et al. 1999) }\end{array}$ & $\begin{array}{l}\text { J. Redemann, } \\
\text { BAERI/NASA } \\
\text { ARC }\end{array}$ & $\begin{array}{l}\text { Slant OD } \sim 0.002( \pm 0.01) \\
\text { Slant WV } \sim 0.0005 \text { to } 0.006 \mathrm{gcm}^{-2} \\
( \pm 8 \%)\end{array}$ \\
\hline $\begin{array}{l}\text { Broad Band Radi- } \\
\text { ometers (BBR) }\end{array}$ & $\begin{array}{l}\text { Radiation fluxes (so- } \\
\text { lar: } 0.2-3.6 \mu \mathrm{m} \& \\
\text { IR: } 4.5-42 \mu \mathrm{m} \text { ) }\end{array}$ & Radiometer & $\begin{array}{l}\text { A. Bucholtz, } \\
\text { NRL }\end{array}$ & Estimated Accuracy: $3-5 \%$ \\
\hline $\begin{array}{l}\text { Cloud Absorption } \\
\text { Radiometer } \\
\text { (CAR) }\end{array}$ & $\begin{array}{l}\text { Radiance, aerosol, } \\
\text { cloud \& Earth sur- } \\
\text { face properties }\end{array}$ & $\begin{array}{l}\text { Angular (cross-track } \\
\text { zenith to nadir) scan- } \\
\text { ning radiometer, } \\
0.340-2.301 \mu \mathrm{m}\end{array}$ & $\begin{array}{l}\text { C. Gatebe, } \\
\text { USRA/NASA } \\
\text { GSFC }\end{array}$ & Radiance absolute accuracy $<5 \%$ \\
\hline $\begin{array}{l}\text { Continuous-Flow } \\
\text { Streamwise Ther- } \\
\text { mal Gradient } \\
\text { Cloud Condensa- } \\
\text { tion Nuclei }\end{array}$ & $\begin{array}{l}\text { Cloud Condensation } \\
\text { Nuclei }(\mathrm{CCN})\end{array}$ & $\begin{array}{l}\text { Supersaturation gener- } \\
\text { ated by relative diffu- } \\
\text { sion of water vapour } \\
\text { and heat (Roberts and } \\
\text { Nenes, 2005) }\end{array}$ & $\begin{array}{l}\text { A. Nenes, Georgia } \\
\text { Tech }\end{array}$ & SS Range: $0.20-0.60 \%, \pm 0.05 \%$ \\
\hline
\end{tabular}




\begin{tabular}{|c|c|c|c|c|}
\hline $\begin{array}{l}\text { (CCN) Counter } \\
\text { (CFSTGC) }\end{array}$ & & & & \\
\hline $\begin{array}{l}\text { Carbon monoxide } \\
\text { By Attenuated } \\
\text { Laser Transmis- } \\
\text { sion (COBALT) }\end{array}$ & $\begin{array}{l}\text { CO mixing ratio } \\
\text { (mole fraction) at a } \\
1-\text { Hz rate based on } \\
\text { measured absorp- } \\
\text { tion, gas tempera- } \\
\text { ture, and pressure } \\
\text { using Beer's Law }\end{array}$ & $\begin{array}{l}\text { off-axis integrated } \\
\text { cavity output spec- } \\
\text { troscopy - TLAS } \\
\text { (Provencal et al. } \\
2005 \text { ) }\end{array}$ & $\begin{array}{l}\text { J. Podolske, } \\
\text { NASA/ARC }\end{array}$ & $\begin{array}{l}\text { Precision: } 0.2 \text { ppbv (1-s averaging } \\
\text { time), uncertainty }<1.0 \%\end{array}$ \\
\hline $\begin{array}{l}\text { Hawaii Group for } \\
\text { Environmental } \\
\text { Aerosol Research } \\
\text { (HiGEAR) }\end{array}$ & $\begin{array}{l}\text { aerosols (Aerosol } \\
\text { number, size, com- } \\
\text { position, volatility, } \\
\text { optical properties; } \\
\text { Clarke et al., 2007; } \\
\text { Shinozuka et al., } \\
2011 \text {. Howell et al., } \\
2006 \text { ) }\end{array}$ & $\begin{array}{l}\text { OPC, PSAP, TDMA, } \\
\text { CN counter. ToF-AMS, } \\
\text { SP2, nephelometer }\end{array}$ & $\begin{array}{l}\text { A. Clarke. U. } \\
\text { Hawaii }\end{array}$ & $\begin{array}{l}\text { See references: Shinozuka et al, } \\
\text { (2011). }\end{array}$ \\
\hline $\begin{array}{l}\text { Project Data Sys- } \\
\text { tem (PDS) }\end{array}$ & $\begin{array}{l}\text { base meteorological } \\
(\mathrm{P}, \mathrm{T}, \mathrm{RH}) \text { and } \\
\text { navigational meas- } \\
\text { urements }\end{array}$ & See reference: Barrick & $\begin{array}{l}\text { John Barrick } \\
\text { NASA/LaRC }\end{array}$ & See references: Barrick \\
\hline $\begin{array}{l}\text { Solar Spectral Flux } \\
\text { Radiometer } \\
\text { (SSFR) }\end{array}$ & Solar spectral flux & $\begin{array}{l}\text { Spectrometer ( } 380- \\
1700 \mathrm{~nm} \text { ) with nadir } \\
\text { and zenith hemispheric } \\
\text { collectors }\end{array}$ & $\begin{array}{l}\text { S. Schmidt, U. } \\
\text { Colorado }\end{array}$ & $\begin{array}{l}\text { Absolute accuracy } 3.5 \% \\
\text { Precision } 1 \%\end{array}$ \\
\hline
\end{tabular}



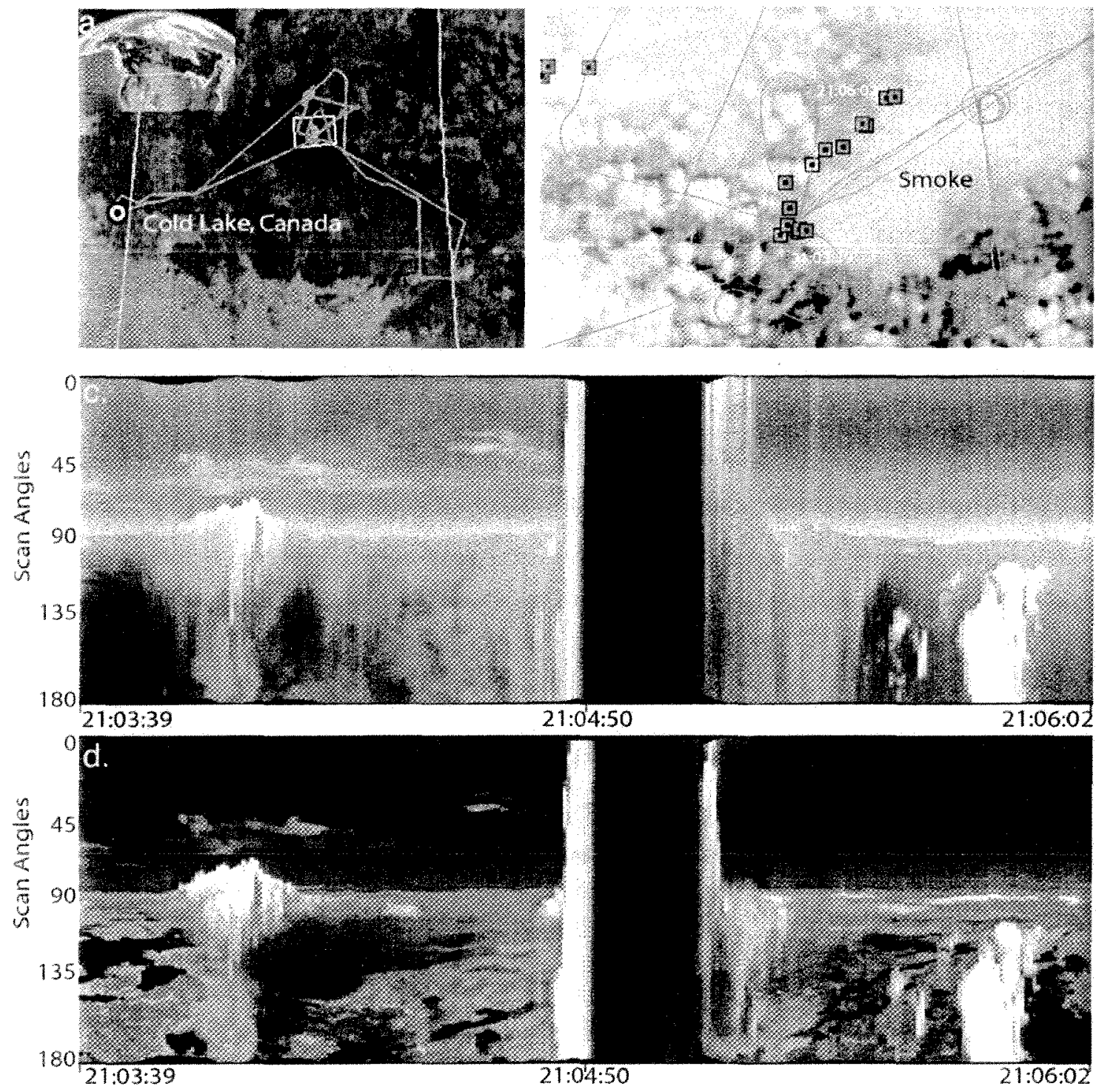

Fig. 1. (a) NASA P-3B flight track 2 July 2008 during the ARCTAS 2008 summer campaign. (b) MODIS/Aqua image taken on 2 July 2008 over the area marked by the rectangle in (a). The red (green) squares are fire locations during Terra (Aqua) overpass at 19:35 UTC (17:55 UTC), and the orange square marks the location of the fire plume that was penetrated by the $\mathrm{P}$ 3B. (c)-(d) CAR quick-look images of the fires taken aboard the NASA P$3 \mathrm{~B}$ over the flight section highlighted in green in (b). A combination of red, green, and blue colors using different CAR bands helps differentiate cloud from smoke, and to see through smoke and identify land surface features such as green vegetation and dark water bodies. The red, green, and blue color assignments in (c) are $0.47,0.38,0.34 \mu \mathrm{m}$ and for (d) 1.66, $1.04,0.38 \mathrm{um}$. 


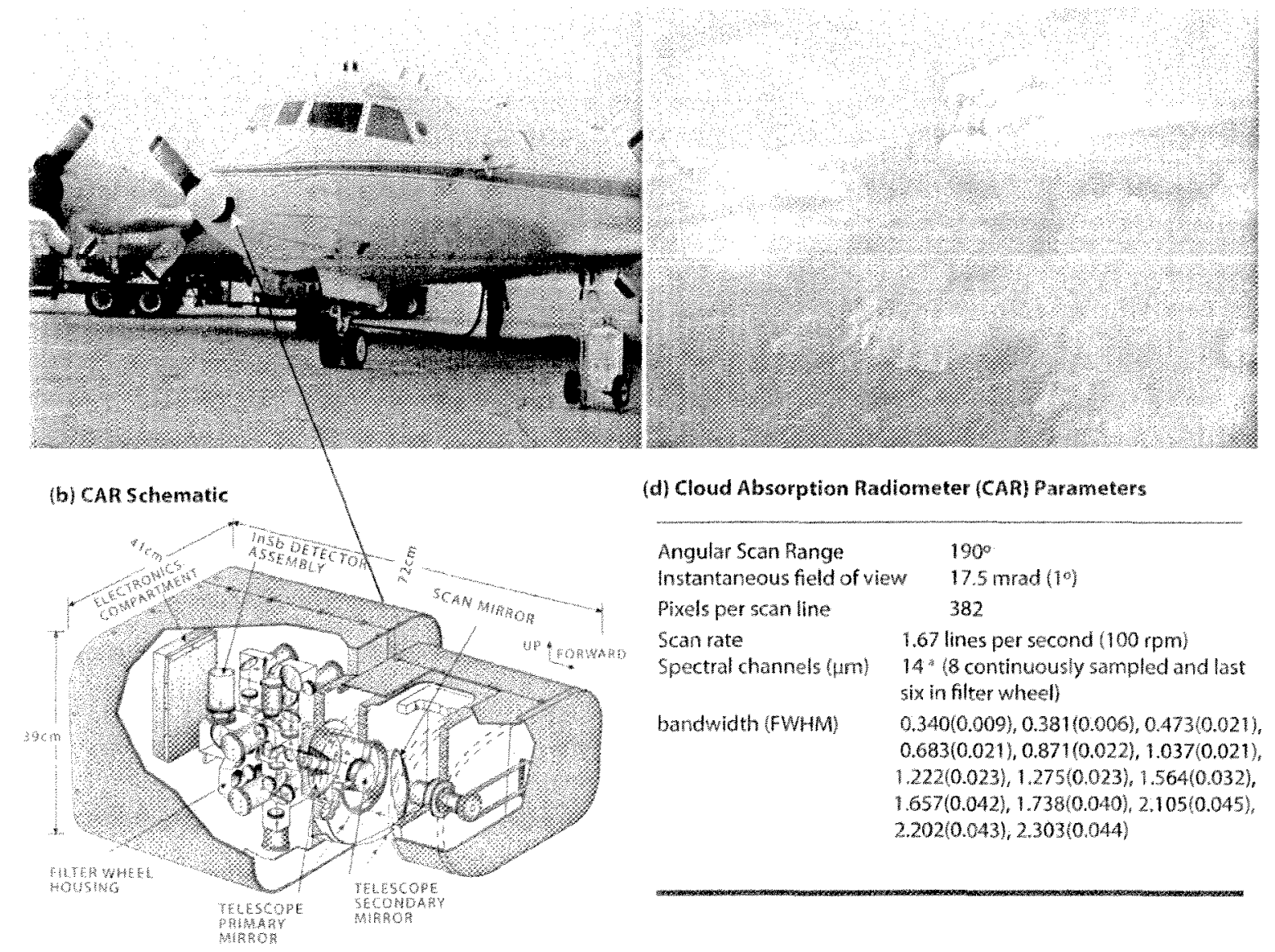

Fig. 2. (a). The NASA P-3B at NASA Ames Research Center, California, USA in June 2008 during the ARCTAS field experiment. (b) Schematic of NASA's Cloud Absorption Radiometer (CAR), which is mounted in the nose of the NASA P-3B aircraft. (c) Picture of the fire plume that the P-3 penetrated on 2 July during ARCTAS. (d) Specifications for the CAR, which contains 14 narrow spectral bands between 0.34 and $2.30 \mu \mathrm{m}$. The CAR flew nine fire missions aboard P-3B in Canada between 28 June and 10 July 2008. 
Fig. 3. Zenith and nadir radiances at $0.472 \mu \mathrm{m}$, on a flight through a pyroCu, between 21:04:45 and 21:05:29 UTC, on 02 July 2008. Pictures a, b and c are

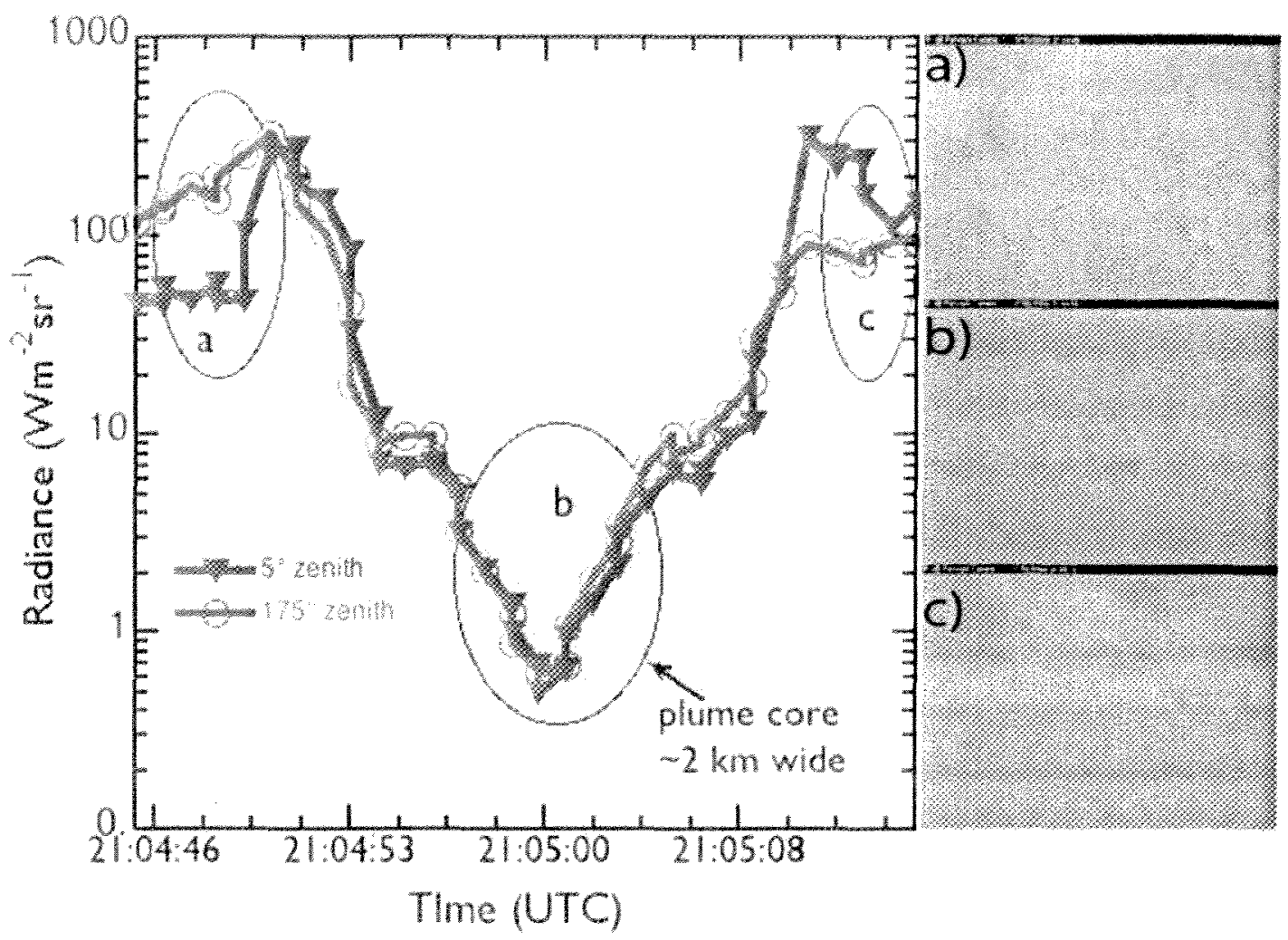

from a forward camera aboard the NASA P-3B, and coincide with entry, core penetration, and exit points of the pyroCu, respectively. The core was very dark, and brownish in color. The distance from the core to the edge of the pyroCu is about $318 \mathrm{~m}$ (assuming average aircraft speed of $132.5 \mathrm{~m} / \mathrm{s}$ ). 

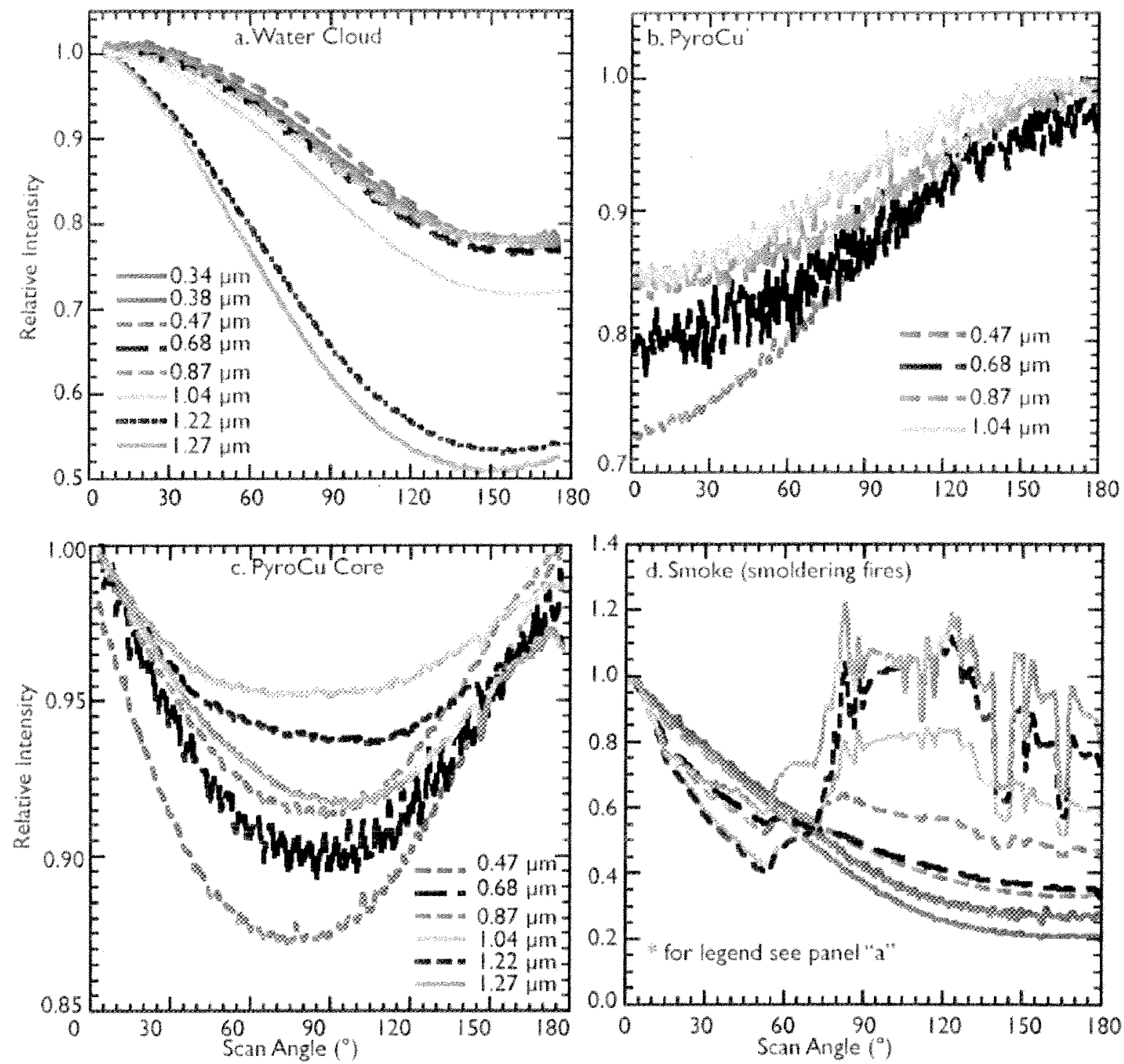

Fig. 4. Relative spectral intensities from CAR as a function of zenith angle for internally scattered radiation measured inside (a) liquid water cloud, (b) pyroCu, (c) core of pyroCu, and (d) thick smoke from smoldering fires with no cloud present. The UV channels are not included in (b) and (c) because of low values of signal-to-noise values. The effects of surface reflectance are clearly seen in the "pure smoke" case (d) at wavelengths, $\lambda$ $20.68 \mu \mathrm{m}$ 


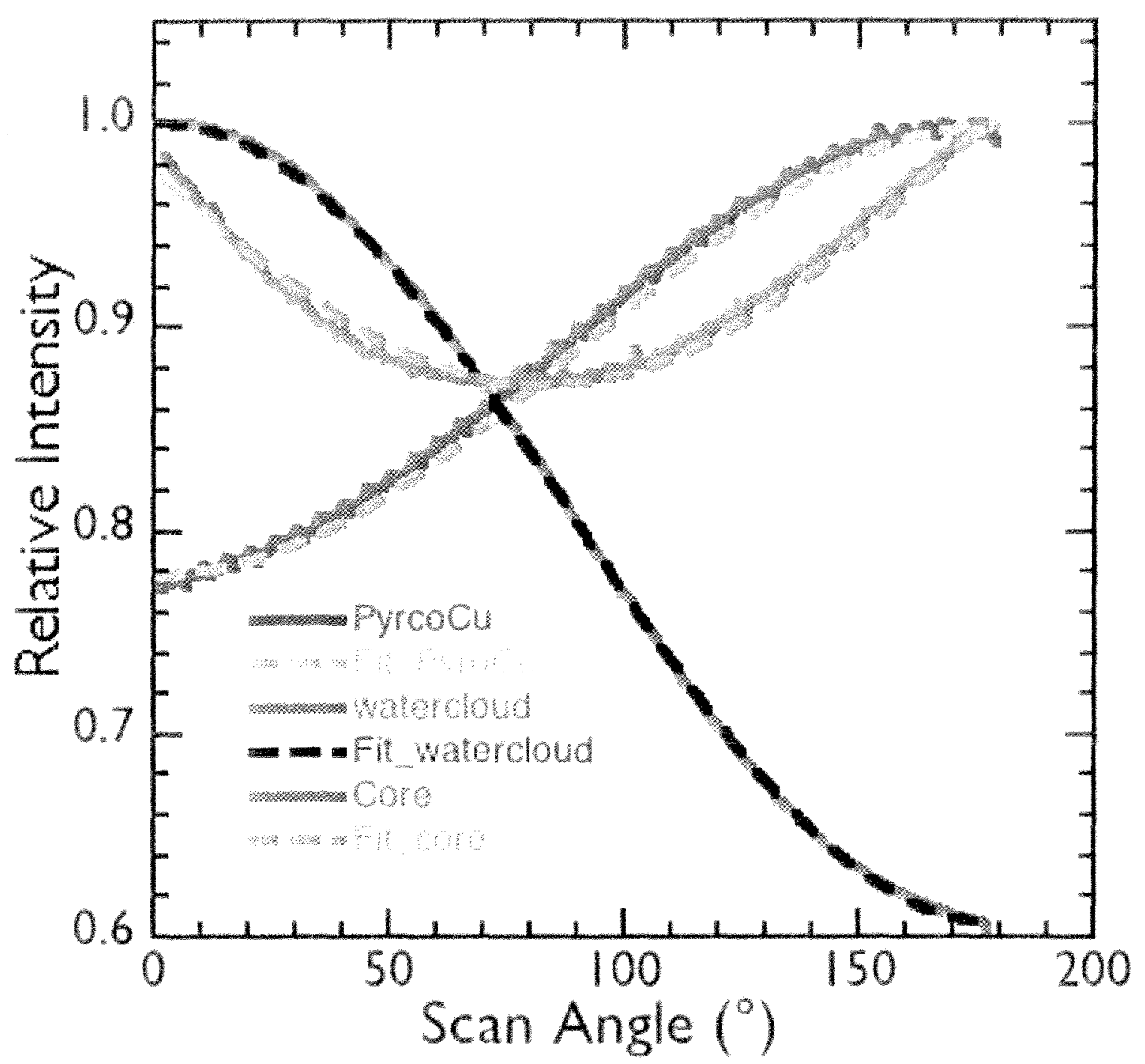

Fig. 5. Observed and fitted relative intensities at $0.472 \mu \mathrm{m}$ represented by solid and dashed lines, respectively, for water cloud, pyroCu and the pyroCu core. The fitted lines for water cloud and pyrocu were generated by a cosine function given in $\mathrm{Eq} .1 \mathrm{~b}$, with parameter " $\mathrm{b}$ " assuming a negative value for the pyroCu case. The pyroCu core was fitted by Eq. 2. 


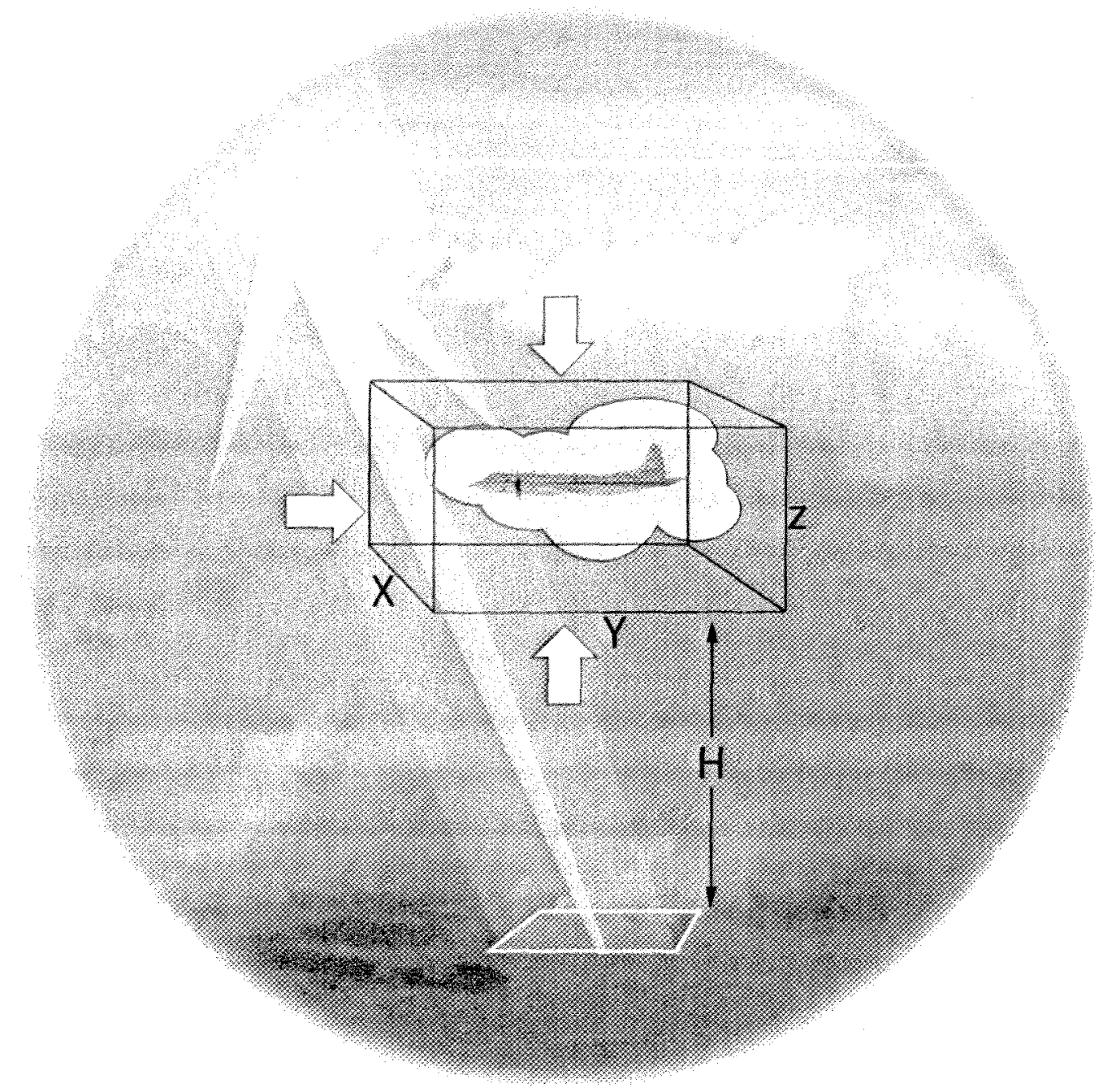

Fig. 6. Illustration of solar illumination paths responsible for the observed radiation patterns in Figs. 4a-c. 


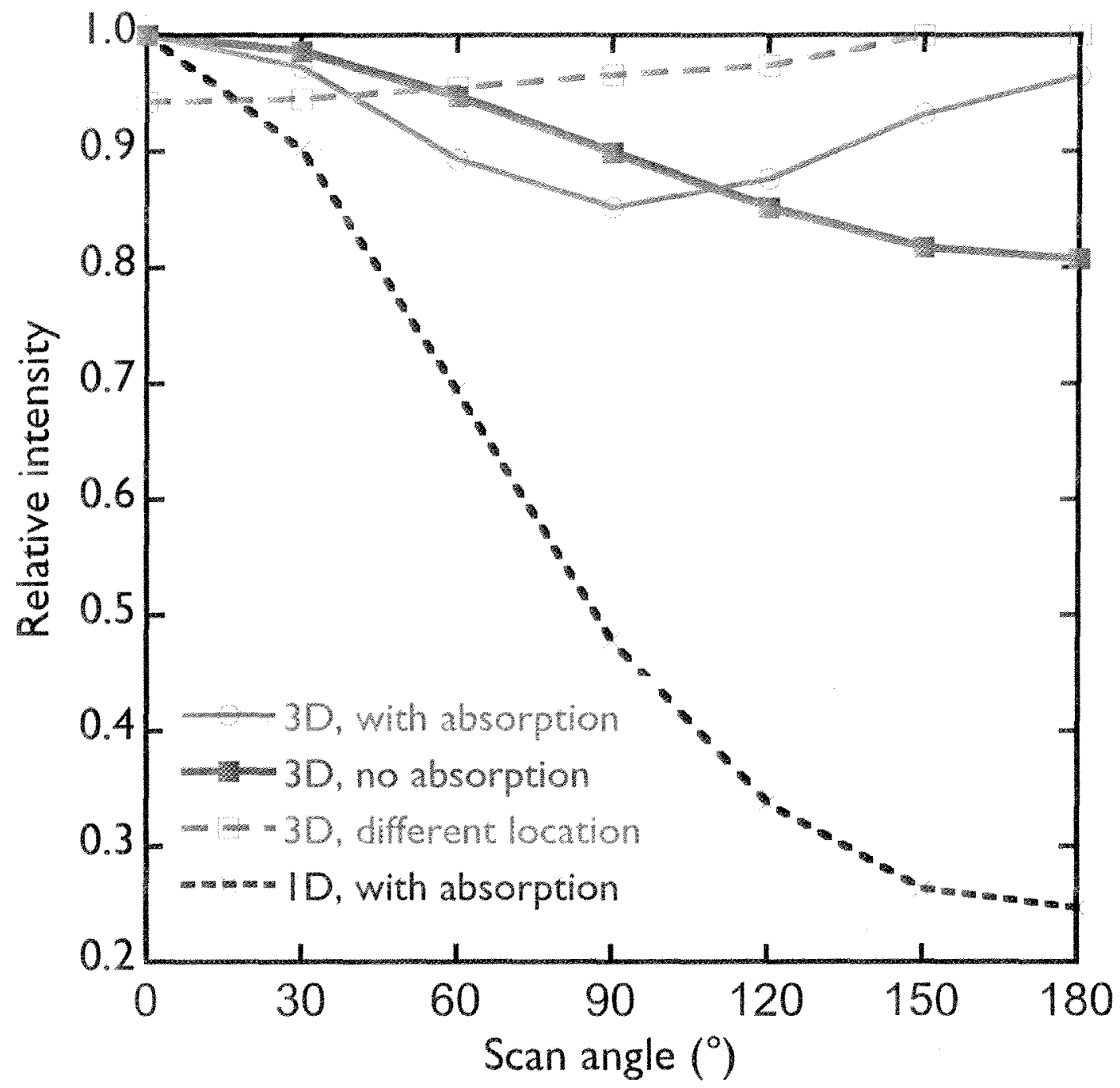

Fig. 7. Simulated CAR data used for understanding the observed behaviors in Fig. 4. The figure shows simulated CAR data for an azimuth perpendicular to the sun $\left(90^{\circ}\right.$ relative azimuth). The black, red, and blue curves are for the horizontal center of the cloud at $1.4 \mathrm{~km}$ altitude. The green curve, simulating behaviors observed at a different (pyroCu) segment of the flight path, is for a point $200 \mathrm{~m}$ away from the sunlit cloud edge at $1.3 \mathrm{~km}$ altitude. 


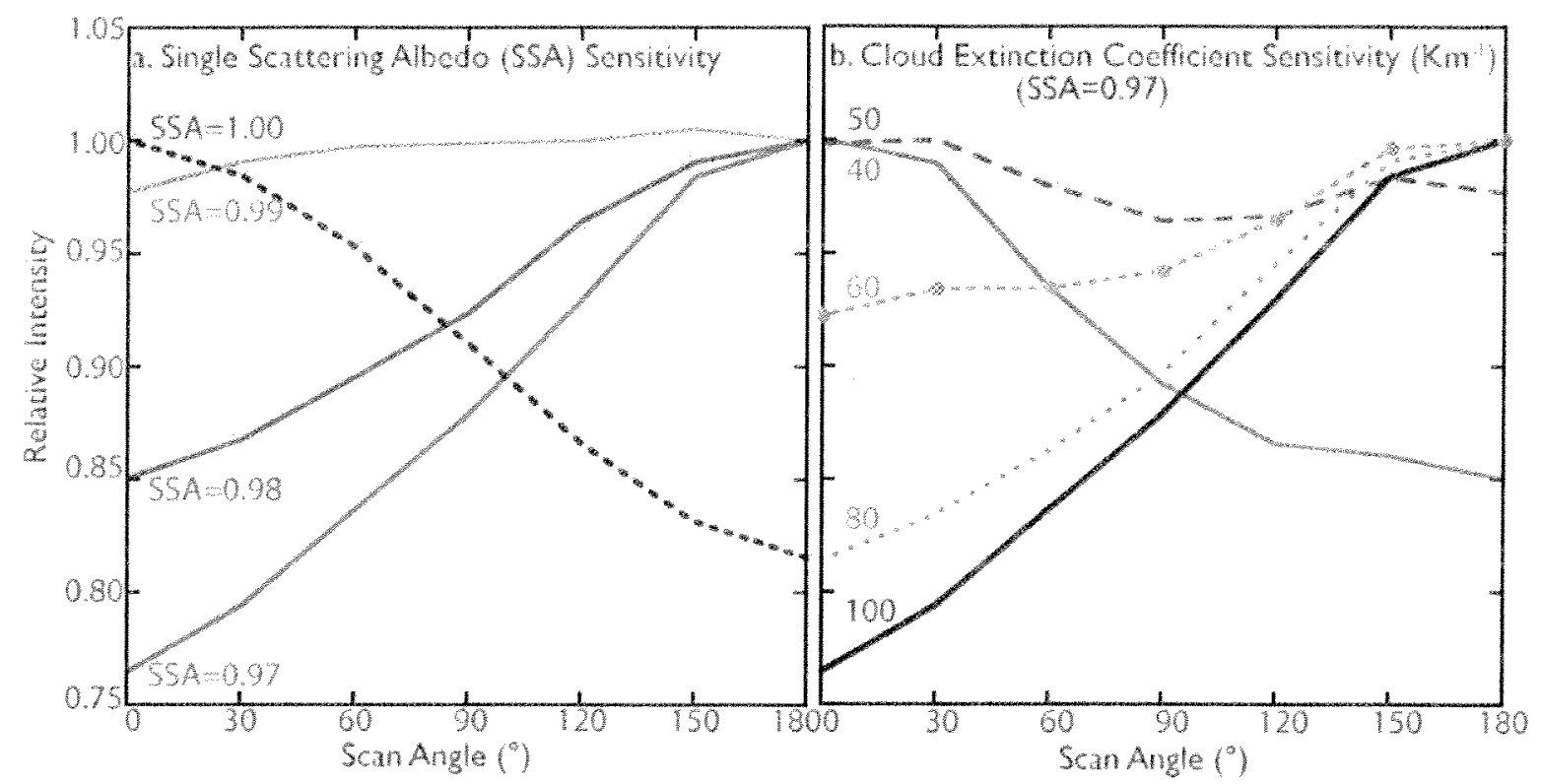

Fig. 8. Impact of (a) variations in single scattering albedo (SSA) at a constant cloud extinction coefficient $\left(100 \mathrm{~km}^{-1}\right)$; and (b) variations in cloud extinction coefficient at a constant SSA (0.97). The simulations are for $85^{\circ}$ relative azimuth at a point $300 \mathrm{~m}$ away from the sunlit cloud edge at $1.3 \mathrm{~km}$ altitude. 